\title{
Nieważność znaku towarowego jako przyczyna zawieszenia procesu cywilnego
}

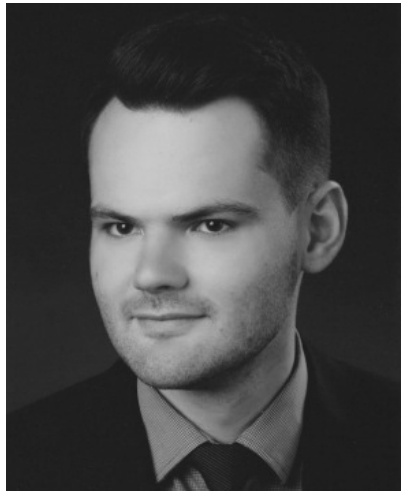

\section{Piotr Łochowski}

Doktorant w Katedrze Prawa Rzymskiego na Wydziale Prawa i Administracji Uniwersytetu Jagiellońskiego, adwokat.

$\triangle$ piotr.lochowski@doctoral.uj.edu.pl https://orcid.org/0000-0002-4262-3746

\section{Invalidity of a Trademark as a Reason for Suspension of Civil Law Proceedings}

\begin{abstract}
The purpose of the article is to discuss the problem of the trademark protection in Polish law. This protection takes place in civil law proceedings. It may be impeded if the defendant begins to challenge the validity of the trademark. The court cannot decide on the validity of the trademark; the decision on the invalidation of the trademark may be taken only by the Patent Office. For this reason, the court should suspend the civil law proceedings which can last for long time. Therefore, in Polish law, following the example of EU law, consideration should be given to the possibility of determining the validity of a trademark also by a court, if such a need occurs during the civil law proceedings.
\end{abstract}

Słowa kluczowe: znak towarowy, proces cywilny

Key words: trademark, civil proceeding

https://doi.org/10.32082/fp.vli51.161

\section{Wprowadzenie}

Znak towarowy stanowi połączenie oznaczenia i towaru (usługi), które służy do odróżniania jednorodnych towarów (usług) różnych podmiotów ${ }^{1}$. Istota i znaczenie znaku towarowego ujawnia się w związku produktem, z przedsiębiorstwem i w końcu - z szeroko rozumianą aktywnością gospo-

1 E. Wojcieszko-Głuszko (w:) System Prawa Prywatnego, t. 14c: Prawo własności przemysłowej, wyd. 1, Warszawa 2017, s. 473. darczą ${ }^{2}$. Samo istnienie oznaczenia nie prowadzi do powstania uprawnienia. Dopiero przyznanie prawa ochronnego w drodze decyzji administracyjnej przez Urząd Patentowy sprawia, że po stronie uprawnionego powstaje monopol na używanie i zarobkowe korzystanie ze znaku towarowego. Prawo to podlega ochronie, ale już nie w postępowaniu administracyjnym przed Urzędem Patentowym, tylko przed

2 Tamże, s. 474. 
sądem powszechnym w procesie cywilnym. Dualistyczny model ochrony powoduje krzyżowanie się kompetencji sądów i Urzędu Patentowego w trakcie sporu o naruszenie prawa ochronnego. Pojawienie się w procesie kwestii zastrzeżonej dla Urzędu Patentowego, którą jest np. rozstrzygnięcie o nieważności ści podejmowane przez stronę, aby nie sankcjonować jej nieuczciwego działania ${ }^{5}$. Na tym kończą się jednak istniejące po stronie sądu instrumenty, pozwalające na zwalczanie nadużywania uprawnień procesowych przez uczestników postępowania. Problem nadużywania przez strony instytucji procesowych nie uszedł

\section{Pozwany, aby zdobyć argumenty na rzecz zawieszenia} postępowania cywilnego, może celowo podnosić zarzut nieważności prawa ochronnego lub inicjować postępowania o stwierdzenie jego nieważności.

prawa do znaku towarowego, powinno prowadzić do zawieszenia postępowania cywilnego. Pozwany, aby zdobyć argumenty na rzecz zawieszenia postępowania cywilnego, może celowo podnosić zarzut nieważności prawa ochronnego lub inicjować postępowania o stwierdzenie jego nieważności. Sytuacja ta może stanowić pole do nadużyć, w szczególności jeśli pozwany nie jest zainteresowany szybkim wydaniem wyroku, spodziewając się niekorzystnego zakończenia sprawy. W obecnie obowiązującym porządku prawnym brak jest skutecznych instrumentów, które pozwoliły na zwalczanie takich zachowań.

Kodeks postępowania cywilnego w art. 3 wyraża generalną dyrektywą skierowaną do stron procesu, nakazującą im, aby ich działania były zgodne z dobrymi obyczajami. Obowiązek dokonywania czynności procesowych zgodnie $\mathrm{z}$ dobrymi obyczajami nie ma jednak istotnego, praktycznego znaczenia i nie daje sędziemu skutecznego instrumentu oddziaływania na strony w procesie ${ }^{3}$. W orzecznictwie wskazuje się, że podtypem działania sprzecznego $\mathrm{z}$ dobrymi obyczajami jest nadużycie uprawnień procesowych przez stronę ${ }^{4}$. Sąd w przypadku takiego działania może pominąć czynno-

3 M. Manowska (w:) M. Manowska (red.), Kodeks postępowania cywilnego, t. 1: Komentarz do art. 1-505, art. 3, nb. 5.

4 Zob. uchwała Sądu Najwyższego z dnia 11 grudnia 2013 r., III CZP 78/13, LEX nr 1506348. jednak uwagi ustawodawcy. Projektowana zmiana kodeksu postępowania cywilnego z 8 stycznia 2019 roku $^{6}$ wprowadza definicję nadużycia prawa procesowego wskazując, że uczestnikom postępowania nie wolno czynić użytku niezgodnego z celem, dla którego je ustanowiono ${ }^{7}$. Nowelizacja przepisów procedury cywilnej ma prowadzić do ograniczenia sytuacji, w której strona podejmuje działania na podstawie i w granicach prawa, nie zmierzając jednak do celu, dla którego dana instytucja została ustanowiona ${ }^{8}$. Posłużenie się klauzulą generalną nadużycia prawa procesowego ma dać podstawę do nałożenia na stronę sankcji finansowej przez wymierzenie grzywny, obciążenie kosztami procesu lub zwiększenie ich wysokości albo podwyższenie stopy zasądzonych odsetek ${ }^{9}$. Innym sposobem radzenia

5 Zob. wyrok Sądu Najwyższego z dnia 27 lipca 2018 r., V CSK 384/17, LEX nr 2525421.

6 Rządowy projekt ustawy o zmianie ustawy - Kodeks postępowania cywilnego oraz niektórych innych ustaw, druk nr 3137 z dnia 8 stycznia 2019 r.

7 Art. 4. Z uprawnienia przewidzianego w przepisach postępowania stronom i uczestnikom postępowania nie wolno czynić użytku niezgodnego z celem, dla którego je ustanowiono (nadużycie prawa procesowego).

8 Rządowy projekt ustawy o zmianie ustawy - Kodeks postępowania cywilnego oraz niektórych innych ustaw, druk nr 3137 z dnia 8 stycznia 2019 roku, s. 30.

9 Tamże, s. 34. 
sobie z nadużyciem prawa procesowego we wskazanej kwestii byłoby zlikwidowanie obowiązującego w polskim prawie dualizmu ochrony i dopuszczenie pozwu wzajemnego o unieważnienie prawa ochronnego oraz przekazanie rozpatrywania spraw z zakresu własności intelektualnej wyspecjalizowanym sądom ${ }^{10}$.

\section{Prejudycjalny charakter decyzji organu administracji publicznej dla procesu cywilnego}

Sąd rozpatrujący sprawę cywilną może zawiesić postępowanie $\mathrm{z}$ urzędu lub na wniosek stron ${ }^{11}$. W przypadku zawieszenia z urzędu może ono mieć charakter obligatoryjny ${ }^{12}$ lub fakultatywny. Przesłanki fakultatywnego zawieszenia postępowania z urzędu zostały wskazane w art. 177 kodeksu postępowania cywilnego (dalej k.p.c.) $^{13}$. Dogmatyka prawa dzieli je na przyczyny wynikające z prejudycjalnego charakteru orzeczenia,

10 Należy wskazać, że przedmiotem prac Rady Ministrów jest projekt zmiany kodeksu postępowania cywilnego i niektórych innych ustaw z dnia 21 marca 2019 (UD 497), na mocy którego miałyby zostać powołane wyspecjalizowane sądy własności intelektualnej, a także umożliwienie powództwa wzajemnego o unieważnienie prawa ochronnego, co prowadziłby do wyeliminowania w znacznym stopniu nadużyć prawa procesowego, których przyczyną jest istnienie w polskim porządku prawnym dualizmu systemu ochrony prawa własności intelektualnej.

11 Podstawy zawieszenia postępowania na wniosek stron zostały wskazane w art. 176 k.p.c. i art. 178 k.p.c.

12 Przesłanki obligatoryjnego zawieszenia postępowania przez sąd z urzędu zostały wskazane $\mathrm{w}$ art. $174 \$ 1$ k.p.c.

13 Art. 177 k.p.c. jako podstawy fakultatywnego zawieszenia procesu cywilnego przez sąd $z$ urzędu wymienia uzależnienie wyniku sprawy od: rezultatu innego toczącego się postępowania cywilnego, treści uprzedniej decyzji organu administracji publicznej; wyniku postępowania toczącego się przed Trybunałem Konstytucyjnym albo Trybunałem Sprawiedliwości Unii Europejskiej, wystąpienia osoby trzeciej z interwencją główną przeciwko wszystkim stronom procesu; ujawnienia się czynu, którego ustalenie w drodze karnej lub dyscyplinarnej mogłoby wywrzeć wpływ na rozstrzygnięcie sprawy cywilnej. Pozostałe dwie przyczyny zawieszenia postępowania wymienione w art. 177 k.p.c., tj. niestawiennictwo stron oraz wskazanie złego adresu pozwanego, nie mają charakteru prejudycjalnego względem przedmiotu postępowania. mającego zapaść $w$ innym postępowaniu oraz bezczynność stron ${ }^{14}$. Decyzja o zawieszeniu, z uwagi na dyspozytywny charakter powołanego przepisu, została oddana swobodnemu uznaniu sądu ${ }^{15}$. Nie oznacza to jednak zupełnej dowolności. Zgodnie z jednolitą linią orzeczniczą Sądu Najwyższego, przed wydaniem postanowienia w przedmiocie zawieszenia postępowania, sąd ma obowiązek rozważenia wszystkich okoliczności sprawy, przez co podjęta decyzja ma być celowa w konkretnej sytuacji procesowej ${ }^{16}$. W nauce prawa wskazuje się, że zawieszenie postępowania zawsze będzie uzasadnione, jeśli jego dalsze prowadzenie skutkowałoby wydaniem dwóch sprzecznych rozstrzygnięć, uniemożliwiających wzajemne wykonanie ${ }^{17}$. Działanie sądu, mieszczące się w zakresie jego władzy dyskrecjonalnej, będzie zatem podlegać ocenie z punktu widzenia celowości podjętej decyzji procesowej ${ }^{18}$. Odmowa zawieszenia procesu w sytuacji tego wymagającej nie jest jednak odrębnie zaskarżalna, może natomiast stanowić uchybienie uzasadniające wniesienie środka odwoławczego, a także podstawę skargi kasacyjnej, jeżeli miało istotny wpływ na wynik sprawy ${ }^{19}$. Zawieszenie będzie celowe, gdy

14 E. Stefańska (w:) M. Manowska (red.), Kodeks postępowania cywilnego. Komentarz, t. 1, wyd. 3, Warszawa 2015, art. 177, nb. 1-3.

15 Zob. postanowienie Sądu Apelacyjnego we Wrocławiu z dnia 16 kwietnia 2012 r., I ACz 654/12, Lex nr 1164098; gdzie wskazano, że zawieszenie postępowania z przyczyn wymienionych w art. 177 k.p.c. następuje z urzędu, niezależnie od inicjatywy stron. Nie ma więc znaczenia, czy przeciwnik procesowy strony inicjującej zawieszenie miał możliwość ustosunkowania się do wniosku.

16 Zob. wyrok Sądu Najwyższego z dnia 14 stycznia 2009 r, IV CSK 358/08, Lex nr 603181.

17 A. Laskowska-Hulisz (w:) A. Marciniak, K. Piasecki (red.), Kodeks postępowania cywilnego, t. 1: Komentarz do art. 1-366, wyd. 7, Warszawa 2016, art. 177, nb. 8.

18 Zob. postanowienie Sądu Najwyższego z dnia 14 września 1967 r., I PZ 52/67, Lex nr 6211; zob. postanowienie Sądu Najwyższego z dnia 14 października 1980 r., IV PZ 62/80, Lex nr 1671958; zob. wyrok Sądu Najwyższego z dnia 10 lipca 2002 r., II CKN 826/00, Lex nr 146172; zob. wyrok Sądu Najwyższego z dnia 24 lutego 2006 r., II CSK 141/05, Lex nr 201027.

19 Zob. wyrok Sądu Najwyższego z dnia 4 grudnia 1998 r., I PKN 486/98, Lex nr 38787. 
do rozpoznania sprawy cywilnej konieczne stanie się wydanie uprzednio konstytutywnego orzeczenia o charakterze prejudycjalnym ${ }^{20}$. W rozumieniu art. 177 k.p.c. oznacza to istnienie potrzeby wydania orzeczenia, stanowiącego przedsąd dla rozpoznawanej sprawy ${ }^{21}$. Treść tego orzeczenia, pośrednio przez powagę rzeczy osądzonej, kształtuje przyszłe rozstrzygnięcie w zawieszonym postępowaniu ${ }^{22}$. Spoczywanie procesu ze względu na kwestię prejudycjalną nie wynika zatem z zasad ekonomii procesowej czy podobieństwa okoliczności faktycznych oraz podstawy prawnej dwóch spraw, ale od zależności rozstrzygnięcia sprawy zawisłej od wyniku innego sporu ${ }^{23}$. Decyzja o zawieszeniu ma przeciwdziałać błędnemu merytorycznie rozpoznaniu sprawy cywilnej ${ }^{24}$.

W judykaturze zwraca się uwagę, aby doszło do zawieszenia na podstawie art. $177 \$ 1$ pkt. 1-4 k.p.c., orzeczenie o charakterze prejudycjalnym ma stanowić niezbędny element stanu faktycznego, konieczny dla wydania rozstrzygnięcia w postępowaniu mającym ulec zawieszeniu ${ }^{25}$. Z tej przyczyny w nauce prawa rozróżnia się dwa rodzaje prejudycjalności: sensu stricto, gdy dana sprawa nie jest możliwa do rozstrzygnięcia przez sąd we własnym zakresie oraz sensu largo, kiedy taka szansa istnieje $\mathrm{e}^{26}$. W pierwszym przypadku zawieszenie postępowania powinno być obligatoryjne, orzeczenie o charakterze prejudycjalnym stanowi bowiem element stanu faktycznego rozpatrywanej sprawy ${ }^{27}, \mathrm{z}$ uwagi na swój konstytutywny charakter ${ }^{28}$. Orzecznictwo

20 P. Grzegorczyk (w:) T. Ereciński (red.), Kodeks postępowania cywilnego. Komentarz, t. 1: Postępowanie rozpoznawcze, wyd. 5, Warszawa 2016, art. 177, nb. 6.

21 Tamże, nb. 6.

22 Zob. wyrok Sądu Najwyższego z dnia 16 listopada 2012 r., III CSK 42/12, Lex nr 1293774.

23 Zob. postanowienie Sądu Najwyższego z dnia 9 lipca 1962 r., I C 82/62, Lex nr 1633518.

24 A. Jakubecki, Prejudycjalność w postępowaniu cywilnym, „Nowe Prawo” 1982, nr 7-8, s. 94.

25 Zob. postanowienie Sądu Najwyższego z dnia 6 listopada 1953 r., I C 1449/53, Lex nr 1633565.

26 A. Jakubecki, Prejudycjalność..., dz. cyt. s. 98.

27 Tamże, s. 99; A. Laskowska, Zawieszenie sądowego postępowania rozpoznawczego $w$ sprawach cywilnych, Warszawa 2009, s. 184.

28 Zob. wyrok Sądu Najwyższego z dnia 30 września 2010 r., I CSK 680/09, Lex nr 622200. co do zasady nie formułuje jednak tak kategorycznych wytycznych dotyczących zawieszenia postępowania w sytuacji, gdy treść innego orzeczenia stanowi konieczny element podstawy rozstrzygnięcia sprawy cywilnej. Wskazuje się raczej na dopuszczalność, a nie obligatoryjność zawieszenia procesu na podstawie art. 177 k.p.c. ${ }^{29}$. Pogląd przeciwny, zgodnie z którym zawieszenie postępowania cywilnego jest obowiązkowe, kiedy w innym postępowaniu ma zapaść konstytutywna decyzja, będąca prejudykatem dla wyroku sądu, został wyrażony przez Sąd Najwyższy w wyroku z 30 września $2010 \mathrm{roku}^{30}$. W przywołanym orzeczeniu wskazano, że niedopuszczalność rozstrzygnięcia w postępowaniu cywilnym kwestii należącej do drogi administracyjnej zachodzi, jeśli decyzja administracyjna dotycząca właśnie tej kwestii będzie miała konstytutywny charakter i tym samym stanowi konieczny element formalnego lub merytorycznego rozstrzygnięcia w postępowaniu sądowym, prejudycjalnie je poprzedzając, wówczas zawieszenie postępowania sądowego jest obligatoryjne ${ }^{31}$. Wydaje się, że jest to, jak do tej pory, jedyna tak stanowcza wypowiedź Sądu Najwyższego, podkreślająca potrzebę automatycznego zawieszenia procesu cywilnego w przypadku wystąpienia kwestii prejudycjalnej w węższym znaczeniu. Powołane w uzasadnieniu przedmiotowego orzeczenia wcześniejsze wyroki Sądu Najwyższego nie są tak kategoryczne ${ }^{32}$. Prowadzone w nich rozważania nie wykluczają możliwości zawieszenia postępowania ze wskazanych przyczyn. Decyzję pozostawiają uznaniu sądu rozpatrującego daną sprawę. Zaprezentowana w wyroku Sądu Najwyższego z dnia 30 września 2010 roku wykładnia art. $177 \$ 1$ pkt 3 k.p.c. wydaje się również nie korespondować z treścią samego przepisu, który ma charakter dyspozytywny. Jednakże sąd powszechny nie może tracić z pola widzenia okoliczności, że jest związany ostateczną decyzją o charakterze konstytutywnym, tj. tworzącą stan prawny,

29 Zob. wyrok Sądu Najwyższego z dnia 15 listopada 2012 r., V CSK 525/11, Lex nr 1276234.

30 Zob. wyrok Sądu Najwyższego z dnia 30 września 2010 r., I CSK 680/09, Lex nr 622200.

31 Tamże.

32 Zob. wyrok Sądu Najwyższego z dnia 27 kwietnia 2006 r., I CSK 22/06, Lex nr 490438; zob. wyrok Sądu Najwyższego z dnia 5 grudnia 1995 r., III CRN 50/95, Lex nr 24941. 
który musi zostać uwzględniony jako element stanu faktycznego w rozstrzyganej sprawie ${ }^{33}$, przez co nie wolno mu samemu rozstrzygnąć kwestii prejudycjalnej dla celów toczącego się procesu ${ }^{34}$. A zatem możliwość zawieszenia postępowania zachodzi, gdy decyzja administracyjna ma prejudycjalne znaczenie w sprawie cywilnej, a sąd powszechny nie może rozstrzygnąć kwestii należącej do drogi postępowania administracyjnego, z uwagi na niedopuszczalność drogi sądowej w postępowaniu cywilnym ${ }^{35}$.

Istotą art. 177 k.p.c., jak już wskazano, jest pozostawienie decyzji o zawieszeniu w gestii władzy dyskrecjonalnej sądu. W orzecznictwie sformułowano kryteria, którymi sąd powinien się kierować przy podejmowaniu decyzji o zawieszeniu. Kryterium takim w szczególności jest warunek celowości. Za trafne należy uznać stanowisko Sądu Najwyższego, w którym został wyrażony pogląd o bezwzględnie dyspozytywnym charakterze art. 177 k.p.c. W wyroku z dnia 24 lutego 2006 roku podkreślono, że jeżeli rozstrzygnięcie rozpoznawanej sprawy zależy od decyzji, jaka może zapaść w innej sprawie, sąd powinien ocenić, czy należy zawiesić postępowani ${ }^{36}$. Z treści art. 177 k.p.c. wynika bowiem, że ustawodawca pozostawił ocenę takiej sytuacji sądowi, a nie nakazał automatycznie zawieszać postępowanie ${ }^{37}$. Wydaje się, że w przypadku zawieszenia procesu w oparciu o art. 177 $\$ 1$ pkt 3 k.p.c. rozstrzygającym winno pozostawać kryterium celowościowe. Takie podejście pozwala organowi sądowemu rozpatrującemu sprawę przeciwdziałać działaniom stron, które dążą do przewłoki postępowania cywilnego. Odmowa zawieszenia procesu nie powoduje jednak, że sąd nabywa uprawnienie do samodzielnego rozstrzygnięcia kwestii prejudycjalnej, kiedy jej rozpatrzenie jest zastrzeżone dla drogi postępowania administracyjnego. Kontynuowanie

33 Zob. uchwała Sądu Najwyższego z dnia 29 czerwca 1995 r., II PZP 2/95, Lex nr 23538.

34 A. Laskowska-Hulisz (w:) Kodeks Postępowania..., dz. cyt., art. 177, nb. 16 .

35 Zob. postanowienie Sądu Najwyższego z dnia 25 lutego 2009 r., II CSK 501/08, Lex nr 528129.

36 Zob. wyrok Sądu Najwyższego z dnia 24 lutego 2006 r., II CSK 141/05, Lex nr 201027.

37 Tamże. procesu przed sądem należy odczytywać za uznanie, że wydane rozstrzygnięcie, mimo braku zawieszenia, nie doprowadzi do powstania w obrocie prawnym dwóch ze sobą sprzecznych orzeczeń.

\section{Znaczenie decyzji o unieważnienie prawa do znaku towarowego dla procesu cywilnego}

Podstawę zawieszenia postępowania cywilnego wymienioną w art. $177 \$ 1$ pkt 3 k.p.c. stanowi uzależnienie rozstrzygnięcia sprawy cywilnej od uprzedniej decyzji organu administracji publicznej. Sądy powszechne są bowiem zobowiązane do respektowania stanów prawnych wytworzonych decyzjami organów administracyjnych, które prowadzą do ustanowienia, zmiany lub zniesienia stosunku prawnego ${ }^{38}$. Do tej kategorii aktów prawnych należy zaliczyć decyzję Urzędu Patentowego o przyznaniu prawa wyłącznego do znaku towarowego, a także o jego unieważnieniu ${ }^{39}$. Istotą ochrony udzielanej przez organ patentowy jest powstanie po stronie uprawnionego monopolu do używania znaku towarowego i czerpania z niego korzyści majątkowych. Dochodzenie roszczeń z tytułu naruszenia tego prawa następuje jednak w postępowaniu przed sądem powszechnym. W procesie cywilnym decyzja Urzędu Patentowego stanowi element stanu faktycznego rozstrzyganej sprawy ${ }^{40}$. Uprawniony, który szuka ochrony musi wykazać bezprawność działań podejmowanych przez podmioty trzecie oraz dowieść, że to jemu przysługuje prawo wyłączne, będące przedmiotem naruszenia. Aby udowodnić ostatnią z wymienionych okoliczności, jako dowód należy przedłożyć

38 P. Grzegorczyk (w:) Kodeks postępowania..., dz. cyt., art. 177, nb. 13 .

39 Zob. uchwała Naczelnego Sądu Administracyjnego z dnia 23 kwietnia 2008 r., II GPS 1/08, Lex nr 368907 i w niej zawarta argumentacja na rzecz deklaratywnego charakteru decyzji o wygaszeniu prawa ochronnego. Stanowisko krytyczne R. Skubisz, M. Trzebiatowski, Prawo własności przemysłowej-decyzja administracyjna - data wygaśnięcia prawa ochronnego na znak towarowy. Glosa do uchwaty NSA z dnia 23 kwietnia 2008 r., II GPS 1/08, „Orzecznictwo Sądów Polskich” 2009, nr 1, s. 15-21.

40 A. Jakubecki (w:) R. Skubisz (red.), System prawa prywatnego, t. 14c: Prawo własności przemysłowej, wyd. 1, Warszawa 2017, s. 638 . 
świadectwo ochronne, z którego wynikają uprawnienia w zakresie prawa do znaku towarowego. Decyzja Urzędu Patentowego wiąże sąd rozpatrujący sprawę o naruszenie, w zakresie zawartego w niej rozstrzygnięcia o przyznaniu powodowi prawa wyłącznego ${ }^{41}$. powództwo winno ulec oddaleniu. Decyzja o unieważnieniu prawa ochronnego do znaku towarowego wywołuje bowiem skutek ex tunc. Stwierdzenie nieważności decyzji o przyznaniu prawa ochronnego zmienia stan faktyczny sporu toczonego przed sądem

\section{Posłużenie się zarzutem nieważności prawa ochronnego lub zainicjowanie przez stronę} pozwaną postępowania o unieważnienie znaku towarowego zmusza sąd do rozpatrzenia, w toku sprawy cywilnej, kwestii stanowiącej $\mathrm{z}$ mocy prawa domenę Urzędu Patentowego.

Sytuacja ta nie wyklucza jednak, że pozwany w toku procesu o naruszenie prawa do znaku towarowego może swobodnie dobierać środki obronne, włączając $\mathrm{w}$ to podniesienie zarzutu nieważności prawa ochronnego przysługującego powodowi. Posłużenie się tym instrumentem lub zainicjowanie przez stronę pozwaną postępowania o unieważnienie znaku towarowego, zmusza sąd do rozpatrzenia, $w$ toku sprawy cywilnej, kwestii stanowiącej z mocy prawa domenę Urzędu Patentowego. Jeśli decyzja o przyznaniu prawa do znaku towarowego okazałaby się nieważna, na przykład na skutek jej późniejszego unieważnienia,

41 Sąd nie jest jednak związany ostateczną decyzją Urzędu Patentowego w sprawie rejestracji znaku towarowego, jeśli chodzi o ocenę faktów stanowiących jednocześnie podstawę rozstrzygnięcia sporu cywilnego; zob. wyrok Sądu Najwyższego z dnia 17 czerwca 2004 r., V CK 280/04, Lex nr 137679. Jest zatem możliwe udzielenie prawa ochronnego na oznaczenie podobne do istniejącego z uwagi na niedostrzeżenie przez Urząd Patentowy podstaw do odmowy rejestracji; zob. postanowienie Sądu Najwyższego z dnia 30 września 1994 r., III CZP 109/94, Lex nr 4115. W stanie prawnym istniejącym po 15 kwietnia 2016 roku sytuacja ta jest jeszcze bardzie prawdopodobna, gdyż Urząd Patentowy nie bada względnych przeszkód rejestracji. powszechnym, eliminuje okoliczność polegającą na istnieniu prawa powoda, w obrębie którego miało dojść do naruszenia. Z tych względów rozstrzygnięcie Urzędu Patentowego stanowi prejudykat dla sądu cywilnego. Przeto rozważenia wymaga to, jaki wpływ na przebieg procesu cywilnego i ewentualne jego zawieszenie wywołuje podniesienie zarzutu nieważności prawa ochronnego, ewentualnie zainicjowanie postępowania przed organem patentowym o jego unieważnienie.

\section{Zawieszenie procesu cywilnego $z$ uwagi na nieważność prawa ochronnego}

Z literalnego brzmienia art. $177 \$ 1$ pkt 3 k.p.c. zdaje się wynikać, że samo zgłoszenie zarzutu nieważności prawa wyłącznego nie daje podstawy do zawieszenia postępowania cywilnego. Stan spoczywania procesu może wywołać sytuacja, w której treść rozstrzygnięcia sądu powszechnego jest zależna od uprzedniej decyzji organu administracyjnego. Kiedy takie postępowanie nie zostało wszczęte, wówczas nie można przyjąć, że wyrok sądu cywilnego pozostaje zależny od treści decyzji administracyjnej. Z chwilą złożenia wniosku o unieważnienie prawa ochronnego, niezależnie czy inicjatorem jest strona procesu cywilnego czy osoba trzecia, spełniona zostaje przesłanka wymieniona 
w art. $177 \$ 1$ pkt 3 k.p.c.; rozstrzygnięcie sprawy cywilnej zaczyna zależeć od uprzedniej decyzji organu administracji publicznej. W tej sytuacji sąd powinien rozważyć, czy istnieją podstawy do zawieszenia postępowania cywilnego. Nie ma on bowiem kompetencji Urzędu Patentowego, aby móc ocenić, czy prawo ochronne zostało przyznane błędnie i winno podlegać unieważnieniu, a w konsekwencji na tej podstawie oddalić powództwo. Powstaje jednak pytanie, w jakim zakresie sąd powszechny pozostaje władny dokonać oceny samego zarzutu nieważności prawa ochronnego i powołanych na tę okoliczność dowodów. W szczególności, gdy postępowanie przed Urzędem Patentowym nie zostało jeszcze zainicjowane. Zarzut nieważności idących komplikacji, gdy pozwany nie wystąpi z wnioskiem do Urzędu Patentowego o unieważnienie znaku towarowego. Mając na uwadze spór toczący się przed sądem powszechnym, jest on podmiotem posiadającym interes prawny do wystąpienia z takim żądaniem. Bierność pozwanego tworzyłaby jednak sytuację, w której mógłby on doprowadzić do uniemożliwienia uzyskania przez powoda efektywnej ochrony prawnej, przeciągając postępowanie sądowe o czas potrzebny Urzędowi Patentowemu do wydania decyzji w przedmiocie unieważnienia znaku towarowego. Nie można wykluczyć, że takie zachowanie naruszającego, będącego pozwanym może stanowić element z góry założonej taktyki procesowej ${ }^{43}$. Odwleczenie wydania

\section{Zarzut nieważności prawa ochronnego} sam w sobie nie stanowi przesłanki hamującej rozpoznanie zgłoszonego roszczenia.

prawa ochronnego, sam w sobie nie stanowi przesłanki hamującej rozpoznanie zgłoszonego roszczenia. Sąd nie może powstrzymać się od zbadania sprawy i oddalić powództwo jako przedwczesne, zasłaniając się koniecznością uprzedniej weryfikacji ważności prawa, na podstawie którego powód domaga się ochrony ${ }^{42}$. Przedstawioną sytuację można rozwiązać na dwa sposoby. Sąd może zawiesić postępowanie i zobowiązać pozwanego do wystąpienia $\mathrm{z}$ wnioskiem do Urzędu Patentowego o unieważnienie prawa ochronnego. Po bezskutecznym upływie wskazanego terminu, sąd musiałby jednak sam zwrócić się do organu patentowego o wydanie decyzji. Możliwe wydaje się również inne rozwiązanie, pozwalające uniknąć zawieszenia procesu. Sąd w przypadku podniesienia zarzutu nieważności prawa ochronnego, rozstrzygnąłby jego zasadność w granicach prowadzonego postępowania. Pierwsza propozycja nie budzi zastrzeżeń dogmatycznych, ale w praktyce może prowadzić do daleko

42 Zob. postanowienie Sądu Najwyższego z dnia 2 marca 2017 r. V CZ 15/17, Lex nr 2278332. wyroku stanowiłoby korzyść po stronie pozwanego, zwłaszcza gdy powodowi nie udzielono na początku postępowania zabezpieczenia roszczenia. Wydaje się, że mając na względzie konstytucyjne prawo do sądu, organy sądowe rozstrzygające spory o naruszenie prawa ochronnego winny przeciwdziałać takim praktykom. Opisane zachowanie pozwanego stanowiłoby jaskrawy przykład nadużycia prawa do obrony w procesie, w szczególności, że działanie takie zazwyczaj podejmowane byłoby w złej wierze. Trudno bowiem wyobrazić sobie stan, w którym pozwany, przekonany o swych racjach nie dążyłby do jak najszybszego wydania korzystnego dla siebie rozstrzygnięcia. Sąd,

43 Przeciwne zapatrywanie wyraził M. Trzebiatowski, Zawieszenie postępowania o naruszenie prawa własności przemy słowej ze względu na postępowanie o jego unieważnienie (na tle orzecznictwa), „Przegląd Sądowy” 2015, nr 7-8, s. 68; autor wskazuje, że zarzutu nieważności znaku towarowego, ze względu na jego doniosłość i ewentualny skutek w postaci zawieszenia procesu, nie powinno się traktować jako elementu zwykłej walki na argumenty czy taktyki procesowej. 
aby przeciwdziałać takim praktykom procesowym, w granicach prowadzonej sprawy, powinien dokonać oceny zarzutu pozwanego dotyczącego nieważności prawa ochronnego ${ }^{44}$. W szczególności, gdy pozwany zaniechał złożenia wniosku do Urzędu Patentowego. Stanowisko to zdaje się znajdować oparcie w orzeczeniu Sądu Najwyższego z dnia 19 września 1986 $\mathrm{roku}^{45}$. Wyrażono w nim pogląd, że sąd powszechny jest władny dokonać ustaleń w przedmiocie zastrzeżonym dla Urzędu Patentowego, gdy pozwany nie skorzysta z przysługujących mu uprawnień. W późniejszym wyroku Sąd Najwyższy wykluczył jednak możliwość badania zarzutu nieważności prawa ochronnego z powodu wyłącznej kognicji Urzędu Patentowego w tym zakresie, stwierdzając, że okoliczność ta nie zawsze musi stanowić podstawę do zawieszenia postępowania $^{46}$. Dlatego wydaje się, że sąd rozpatru-

44 Zob. postanowienie Sąd Najwyższy z dnia 23 sierpnia 1990 r., I CZ 106/90, Lex nr 3664. Na mocy powołanego postanowienia Sąd Najwyższy stwierdził, jeszcze na gruncie nieobowiązującej już ustawy o wynalazczości, że sąd prowadzący postępowanie o zaniechanie naruszenia patentu (art. 57 ust. 1 ustawy o wynalazczości z dnia 19 października 1972 r. - tekst jedn.: Dz.U. z 1984 r., nr 33, poz. 177) jest władny rozpoznać zarzut pozwanego, że prowadzona przez niego produkcja nie jest objęta patentem udzielonym powodowi, nie uzasadnia to zawieszenia postępowania i odesłania stron na drogę postępowania spornego przed Urzędem Patentowym w celu uzyskania decyzji, o której mowa w art. 114 ust. 1 pkt 6 w związku z art. 19 ustawy o wynalazczości. Ustalenia, czy produkcja prowadzona przez pozwanego jest objęta patentem udzielonym powodowi, dokonuje samodzielnie sąd rozpoznający sprawę.

45 Zob. wyrok Sądu Najwyższego z dnia 19 września 1986 r., IV PR 286/86, Lex nr 470982. Sąd Najwyższy w przywołanym wyroku, jeszcze na gruncie nieobowiązującej już ustawy o wynalazczości, uznał wszak, że Urząd Patentowy jest najbardziej kompetentnym organem dla dokonania wykładni treści dokumentu patentowego, $\mathrm{w}$ tym zastrzeżeń patentowych określających zakres udzielonej ochrony. Prowadzi to do wniosku, że sąd dokonuje samodzielnie ustaleń w tym przedmiocie tylko wówczas, gdy pozwany nie wykorzysta przysługujących mu w tym zakresie uprawnień z art. 114 ust. 1 pkt 6 ustawy o wynalazczości.

46 Zob. wyrok Sądu Najwyższego z dnia 2 marca 2017 r., V CZ 15/17, Lex nr 2278332. jący sprawę o naruszenie prawa do znaku towarowego powinien ustosunkować się do zarzutu nieważności prawa ochronnego, choćby z tego względu, aby zbadać czy argumenty pozwanego są na tyle doniosłe, że mogą prowadzić do unieważniania decyzji o udzieleniu prawa wyłącznego. Ocena zarzutu nieważności prawa do znaku towarowego winna być jednak dokonywana jedynie od strony negatywnej. W konsekwencji sąd może uznać, że zarzut ten jest pozbawiony podstaw i dalej procedować lub uznać, iż jest on zasadny i zawiesić postępowanie, a nawet zwrócić się samemu w tej sprawie do Urzędu Patentowego. Należy podkreślić, że sąd w tej sytuacji nie rozpatrywałby czy prawo ochronne zostało przyznane wadliwe, ale czy argumenty podnoszone przez pozwanego są na tyle uzasadnione, że przyznanie racji powodowi mogłoby prowadzić do wydania wyroku sprzecznego z ewentualną decyzją Urzędu Patentowego. Niepożądanym wydaje się bowiem, aby w obrocie prawnym istniało orzeczenie wydane w oparciu o decyzję, która została następnie unieważniona. Zawieszenie postępowania w oparciu o art. $177 \$ 1$ pkt 3 k.p.c. ma właśnie temu przeciwdziałać. Przy czym nie może ono następować automatycznie, gdy tylko pozwany zgłosi zarzut nieważności prawa ochronnego udzielonego powodowi. Inaczej art. $177 \$ 1$ pkt 3 k.p.c. stałby się wygodnym instrumentem tamującym proces, czyniąc ochronę uprawnionego, w przypadku naruszenia prawa wyłącznego, mocno iluzoryczną. Zapatrywanie to wydaje się mieć swe uzasadnienie w wyroku Sądu Najwyższego z dnia 2 marca 2017 roku, w którym zauważono, że sąd nie może uchylić się od obowiązku rozpatrzenia kwestii dotyczących istoty sprawy, choćby te mogły i powinny zostać powołane w postępowaniu przed Urzędem Patentowym ${ }^{47}$. Możliwość wystąpienia przesłanki hamującej proces nie zwalnia sądu od zbadania materialnej podstawy roszczenia, do chwili rozstrzygnięcia sprawy przed Urzędem Patentowym, co będzie przesądzać w przyszłości o istnieniu samego roszcze$\mathrm{nia}^{48}$. Dlatego sąd, podejmując decyzję procesową co do dalszego prowadzenia postępowania powinien ocenić doniosłość zarzutu pozwanego i rozstrzygnąć, czy w świetle przedstawionych faktów i dowo-

47 Tamże.

48 Tamże 
dów celowym jest jego zawieszenie. Niemniej jednak, zgodnie z decyzją Urzędu Patentowego, której ważność pozwany może kwestionować, prawo ochronne przysługuje nadal powodowi, unieważnić może je wyłącznie organ patentowy. Działanie sądu polegające na ustosunkowaniu się do wniosku o zawieszenie postępowania, z powodu nieważności znaku towarowego, nie wpływa na skuteczność prawa ochronnego.

Kolejnym przykładem nadużywania instytucji zawieszenia procesu w sprawach z zakresu prawa własności intelektualnej jest sytuacja, w której pozwany, przewidując wytoczenie przeciwko niemu powództwa o naruszenie znaku towarowego, wystąpi wcześniej do Urzędu Patentowego z wnioskiem o unieważnienie naruszanego prawa ochronnego. Dla naruszającego, wniosek o unieważnienie prawa ochronnego, stanowi narzędzie do uzyskania argumentów na rzecz przyszłego zawieszenia procesu cywilnego. Spoczywanie procesu będzie bowiem leżało, w większym stopniu, w jego interesie. Postępowanie przed Urzędem Patentowym może zatem stać się jedynie instrumentem oddziaływania na przebieg procesu cywilnego, w celu jego paraliżowania. Pozwany będzie mógł wówczas nie tylko podnieść zarzut nieważności znaku towarowego, ale również wskazać, że poczynił już kroki, aby przedmiotowe prawo ochronne wygasić. Tego typu taktyka procesowa jest często spotykana w sprawach z zakresu własności intelektualnej. W szczególności pod nazwą „strategia torpedy”, która polega na wszczynaniu postępowania o stwierdzenie nienaruszenia patentu w celu udaremnienia wszczęcia powództwa w innych krajach Unii Europejskiej o jego naruszenie ${ }^{49}$. Stąd też warto się zastanowić, czy dualistyczny model ochronny praw własności przemysłowej obowiązujący w polskim porządku prawnym jest rozwiązaniem optymalnym.

\section{Sprzeciwowy model rejestracji znaków towarowych, a problem zawieszenia postępowania z powodu nieważności prawa ochronnego}

Z dniem 15 kwietnia 2016 roku zmianie uległ krajowy system udzielania prawa ochronnego na znaki towarowe ${ }^{50}$. Pełną weryfikację zgłoszenia, polega-

49 M. du Vall, Prawo patentowe, Warszawa 2008, s. 432.

50 Dz.U. 2015 poz. 1615. jącą na badaniu, czy nie zachodzą względne lub bezwzględne przeszkody rejestracji, zastąpiono modelem, nazywanym w dogmatyce prawa "sprzeciwowym”. Wskutek nowelizacji Urząd Patentowy na etapie rejestracji oznaczenia sprawdza tylko istnienie bezwzględnych $^{51}$ przeszkód w udzieleniu prawa ochronnego ${ }^{52}$. Nie bada już z urzędu istniejących znaków towarowych i znaku stanowiącego przedmiot zgłoszenia. W przeszłości znaki te były ze sobą porównywane, nawet mimo niezachodzenia między nimi stosunku konkurencji5 ${ }^{3}$. Tak szeroką weryfikację wniosków uzasadniano potrzebą zagwarantowania ochrony podmiotom uprawnionym z wcześniej zarejestrowanych znaków towarowych. Prawa te mogłyby zostać naruszone, gdyby dokonano rejestracji oznaczenia powodującego konfuzję $^{54}$. Poprzednio obowiązujący model, z jego daleko idącą kontrolą, miał również zabezpieczać konsumentów przed wprowadzaniem w błąd przez mylące

51 Należy jednak zwrócić uwagę, iż zgodnie z nowo wprowadzonym ust. 6 art. 146 p.w.p. dla zgłoszenia znaku towarowego podlegającego ogłoszeniu Urząd Patentowy sporządza zawiadomienie o istnieniu identycznych lub podobnych znaków towarowych z wcześniejszym pierwszeństwem, przeznaczonych do oznaczania takich samych lub podobnych towarów i przekazuje je zgłaszającemu. Nie można więc definitywnie twierdzić, iż względne przeszkody udzielenia prawa ochronnego na znak towarowy nie są w ogóle przedmiotem badania Urzędu Patentowego bez wniesienia sprzeciwu wobec zgłoszenia; tak: M. Lampart, Prawo własności przemysłowej. Komentarz do zmian wprowadzonych ustawą z dnia 11 wrześ nia 2015 r. o zmianie ustawy - Prawo własności przemysłowej, Warszawa 2016, art. 146, nb. 1. W tym kontekście na uwagę zasługuje wyrok Sądu Apelacyjnego w Warszawie z dnia 25 stycznia 2007 roku, w którym sąd uznał, że brak jest podstaw do zawieszenia postępowania w trybie art. 177 k.p.c. skoro powód od dłuższego czasu wiedział, iż podmiot konkurencyjny dokonuje rejestracji patentu i do zakończenia procedury w sprawie jego udzielenia nie uczynił nic, aby przeciwdziałać udzieleniu prawa patentowego konkurentowi; zob. wyrok Sądu Apelacyjnego w Warszawie z dnia 25 stycznia 2007 r., I ACa 819/06, Lex nr 516527.

52 Katalog bezwzględnych przyczyn odwoławczych wymienia art. 129 p.w.p.

53 K. Mania, Domena internetowa jako przedmiot polubownego rozstrzygania sporów, Warszawa 2016, s. 84.

54 Tamże. 
znaki towarowe używane w obrocie ${ }^{55}$. Na skutek nowelizacji, względne przeszkody rejestracji są brane pod uwagę w procesie rejestracji nowego oznaczenia, jeśli uprawniony z wcześniejszego prawa ochronnego lub podmiot, którego prawa osobiste lub majątkowe zostały naruszone, wniesie sprzeciw wobec rozpatrywanego zgłoszenia. W konsekwencji ocenę, czy wobec nowego znaku towarowego zachodzą względne przeszkody rejestracji, oddano tylko zainteresowanym podmio-

\section{Podsumowanie $i$ wnioski de lege ferenda}

Zmiana przepisów regulujących rejestrację znaków towarowych rzuca nowe światło na problem zawieszenia postępowania cywilnego na skutek kwestionowania ważności prawa ochronnego. Obecnie w obrocie prawnym funkcjonują znaki towarowe uzyskane wedle poprzednich zasad, jak i te, wobec których nie kontrolowano istnienia względnych przeszkód rejestracji. Wydaje się, że z uwagi na obniżony poziom weryfika-

\section{Rozwiązanie wzorowane na prawie europejskim} z pewnością usprawniałoby krajowe postępowanie cywilne, eliminując ryzyko używania zarzutu nieważności oraz wniosku o zawieszenie postępowania jako instrumentu do paraliżowania
postępowania o naruszenie prawa ochronnego.

tom $^{56}$. Urząd Patentowy na etapie zgłoszenia nie ocenia już ryzyka zaistnienia konfuzji między istniejącymi oznaczeniami a nowym znakiem towarowym w celu eliminowana potencjalnych pól konfliktu w obrocie gospodarczym ${ }^{57}$. Nowy model przyznawania praw ochronnych zwiększa zatem prawdopodobieństwo występowania naruszeń wskutek rejestracji oznaczeń podobnych i konkurencyjnych względem już istniejących. Niesie również za sobą obniżenie pewności uzyskiwanych praw, które obecnie mogą być częściej przedmiotem postępowania w sprawie unieważnienia znaku towarowego z powodu ograniczenia zakresu kontroli zgłoszeń rejestracyjnych ${ }^{58}$.

55 Tamże, s. 85

56 K. Sztobryn, (Nie tylko) krytyczne spojrzenie na nowe przepisy ustawy prawo własności przemysłowej dotyczące sprzeciwu wobec zgłoszenia znaku towarowego, „Przegląd Prawa Handlowego" 2016, nr 8, s. 29.

57 Tamże, s. 29.

58 Tamże. cji, w stosunku do praw ochronnych przyznanych po dniu 15 kwietnia 2016 roku, istnieje większe prawdopodobieństwo zasadności zarzutu nieważności takiego prawa. Niewątpliwie będzie ono jeszcze rosło, gdy decyzję o przyznaniu prawa wyłącznego nie poprzedziło postępowanie ze sprzeciwu. Zmiana modelu rejestracji znaków towarowych stanowi jednocześnie dostosowanie porządku krajowego do prawa Unii Europejskiej. Wydaje się jednak, że została ona przeprowadzona w sposób niepełny. Prawo unijne wypracowało jednolity model rozwiązywania problemu pojawienia się zarzutu nieważności prawa ochronnego, dopuszczając wniesienie powództwa wzajemnego o unieważnienie wzoru wspólnotowego ${ }^{59} \mathrm{i}$ unijnego

59 Art. 24 ust. 1 Rozporządzenie Rady (WE) nr 6/2002 z dnia 12 grudnia $2001 \mathrm{r}$. w sprawie wzorów wspólnotowych (Dz.Urz. UE L 2002, nr 3, str. 1) wskazuje, że wzór wspólnotowy uważa się za nieważny na wniosek złożony w urzędzie, zgodnie z postępowaniem według tytułów VI i VII lub z powództwa 
znaku towarowego ${ }^{60}$ przed sąd rozpatrujący sprawę $\mathrm{z}$ naruszenia prawa ochronnego. Rozwiązanie wzorowane na prawie europejskim $z$ pewnością usprawniałoby krajowe postępowanie cywilne, eliminując ryzyko używania zarzutu nieważności oraz wniosku o zawieszenie postępowania, jako instrumentu do paraliżowania postępowania o naruszenie prawa ochronnego. Regulacja unijna eliminuje również ryzyko sytuacji, w której sąd powszechny prowadziłby postępowanie i orzekł o naruszeniu prawa, które zostałoby następnie unieważnione. W przypadku zgłoszenia o unieważnieniu prawa ochronnego ${ }^{63}$. Widzimy zatem, że w orzecznictwie unijnym również dostrzeżono problem potencjalnego przedłużenia postępowania w sprawie ochrony znaków towarowych w przypadku podnoszenia zarzutu nieważności tego prawa. Oddanie do rozstrzygnięcia jednej jak i drugiej kwestii temu samemu organowi wydaje się rozwiązaniem jednak bardziej efektywnym od nadal obowiązującego w polskim prawie modelu dualistycznego.

W obecnym stanie prawnym podstawowym zadaniem sądu rozstrzygającego sprawę o naruszenie prawa

\section{Podstawowym zadaniem sądu rozstrzygającego} sprawę o naruszenie prawa wyłącznego jest dążenie do uniknięcia sprzeczności między
jego oceną, a oceną Urzędu Patentowego.

powództwa wzajemnego o unieważnienie unijnego prawa ochronnego sąd jest zobowiązany najpierw zbadać tę kwestię, a następnie orzec co do naruszenia ${ }^{61}$. Nie oznacza to jednak, że sąd rozpatrujący obydwie sprawy musi wstrzymać się aż do uprawomocnienia się orzeczenia w przedmiocie unieważnienia. Może on bowiem obie sprawy rozpoznać równocześnie, co pozwoli uniknąć przewlekłości postępowania ${ }^{62}$. Przewlekłość mogłaby wystąpić na skutek wnoszenia bezprzedmiotowych środków odwoławczych, tylko w celu opóźnienia wystąpienia prawomocności orzeczenia

wzajemnego przez sąd do spraw wzorów wspólnotowych w postępowaniu o naruszenie.

60 Art. 59 i art. 60 Rozporządzenia Parlamentu Europejskiego i Rady (UE) 2017/1001 z dnia 14 czerwca 2017 r. w sprawie znaku towarowego Unii Europejskiej (Dz.U. UE L z dnia 16 czerwca 2017 r.) dopuszcza wystąpienie z roszczeniem wzajemnym w ramach procesu o naruszenie znaku towarowego, którego przedmiotem jest żądanie unieważnienia wspólnotowego znaku towarowego.

61 Zob. wyrok TSEU z dnia 19 października 2017 r., C-425/16, Lex nr 2376845.

62 Tamże. wyłącznego wydaje się dążenie do uniknięcia sprzeczności między jego oceną, a oceną Urzędu Patentowego w sytuacji, w której pozwany zgłasza zarzut nieważności znaku towarowego lub wnosi o zawieszenie procesu z powodu toczącego się postępowania o unieważnienie. Ustawodawca nie wyposażył sądów powszechnych w skuteczne instrumenty do zwalczania działań stron, chcących przewlekać proces cywilny z wyżej wskazanych względów. Zawieszenie postępowania w sprawie naruszenia, do czasu wydania decyzji przez Urząd Patentowy, nie może następować automatycznie, inaczej stałoby się polem do nadużyć ze strony pozwanych ${ }^{64}$. Prowadziłoby również do faktycznego pozbawienia sądu możliwości rozstrzygnięcia sprawy, czyli istotnej kompetencji z punktu widzenia ochrony indywidualnych interesów podmiotów prawa cywilnego ${ }^{65}$. Należy

63 Tamże.

64 B. Czachórska-Jones (w:) J. Szwaja, A. Szajkowski (red.), System prawa własności intelektualnej, t. 3: Prawo wynalazcze, Warszawa 1990, s. 315.

65 Zob. uchwała Sądu Najwyższego z dnia 23 lipca 2008 r., III CZP 52/08, Lex nr 408406. Należy jednak zaznaczyć, że 
zgodzić się z poglądem, że konstytutywna decyzja administracyjna jest zdarzeniem prawnym $i$ jako fakt wchodzi w skład podstawy faktycznej procesu, zatem sąd nie może na potrzeby postępowania cywilnego kreować faktów ${ }^{66}$. Toteż w przypadku zgłoszenia zarzutu nieważności prawa ochronnego, czy też już trwającego postępowania o unieważnienie sąd musi brać pod uwagę okoliczność, że decyzja, w oparciu o którą ma wydać rozstrzygniecie, może zostać usunięta z obrotu prawnego ze skutkiem ex tunc. Wyrok wydany w oparciu o wygaszone prawo ochronne będzie wadliwy. Nadto przepisy postępowania cywilnego uniemożliwiają zakwalifikowanie takiej decyzji administracyjnej, wydanej po uprawomocnieniu się orzeczenia sądowego, jako podstawy skargi o wznowienie postępowania ${ }^{67}$. Nietrudno sobie wówczas wyobrazić, że były pozwany, który musiał zapłacić odszkodowanie zasądzone na podstawie wadliwego wyroku wystąpi o odszkodowanie do Skarbu Państwa. Ustawodawca, pozostawiając dualizm ochrony prawnej w sprawach z zakresu prawa własności przemysłowej, przynajmniej w zakresie nieważności praw wyłączonych, doprowadził do sytuacji, w której sądy powszechne mają do rozwiązania zadanie przypominające kwadraturę koła. Zmiana krajowych regulacji na wzór unijnych i dopuszczenie powództwa wzajemnego o unieważnienie znaku towarowego stanowiłyby krok we właściwą stronę. Wartym rozważenia byłoby również utworzenie osobnych wydziałów, czy też sekcji w ramach istniejących już jednostek, powołanych wyłącznie do rozstrzygania spraw dotyczących prawa własności intelektualnej. Naprzeciw potrzeby obrotu prawnego wychodzi rządowy projekt zmiany kodeksu postępowania cywilnego, który ma powołać do życia w sądach okręgowych wydziały do spraw własności intelektualnej ${ }^{68}$. Nowelizacja kodeksu prze-

przywołana uchwała zapadła w sprawie rozpatrywanej na podstawie przepisów ustawy o ochronie konkurencji i konsumentów przez co dla sporów wynikłych na tle ustawy prawo własności przemysłowej może stanowić jedynie wskazówkę interpretacyjną.

66 A. Jakubecki (w:) System prawa..., dz. cyt., s. 646.

67 Zob. wyrok Sądu Najwyższego z dnia 18 lutego 2016 r., II CSK 282/15, Lex nr 1991181.

68 Projekt Rady Ministrów zmiany kodeksu postępowania cywilnego i niektórych innych ustaw z dnia 21 marca 2019 r. (UD 497). widuje również wprowadzenie postępowania odrębnego, regulującego spory wynikłe na tle powyższych kwestii oraz likwidację dualizmu systemu ochrony praw własności intelektualnej. Projektowana zmiana dopuszcza powództwo wzajemne o unieważnienie prawa ochronnego ${ }^{69}$. Zaproponowane zmiany wydają się zmierzać $\mathrm{w}$ dobrym kierunku, natomiast $\mathrm{z}$ ich szczegółową oceną trzeba się wstrzymać aż do chwili przedłożenia ostatecznego projektu ustawy.

\section{Bibliografia}

Czachórska-Jones B. (w:) Szwaja J., Szajkowski A. (red.), System prawa własności intelektualnej, t. 3: Prawo wynalazcze, Warszawa 1990

Grzegorczyk P. (w:) Ereciński T. (red.), Kodeks postępowania cywilnego. Komentarz, t. 1: Postępowanie rozpoznawcze, wyd. 5, Warszawa 2016.

Jakubecki A., Prejudycjalność w postępowaniu cywilnym, „Nowe Prawo" 1982, nr 7-8.

Jakubecki A. (w:) Skubisz R. (red.), System prawa prywatnego, t. 14c: Prawo własności przemysłowej, wyd. 1, Warszawa 2017. Lampart M., Prawo własności przemysłowej. Komentarz do zmian wprowadzonych ustawą z dnia 11 września 2015 r. o zmianie ustawy - Prawo własności przemysłowej, Warszawa 2016

Laskowska A., Zawieszenie sądowego postępowania rozpoznawczego w sprawach cywilnych, Warszawa 2009.

Laskowska-Hulisz A. (w:) Marciniak A., Piasecki K. (red.), Kodeks postępowania cywilnego, t. 1: Komentarz do art. 1-366, wyd. 7, Warszawa 2016

Mania K., Domena internetowa jako przedmiot polubownego rozstrzygania sporów, Warszawa 2016.

Skubisz R., Trzebiatowski M., Prawo własności przemysłowejdecyzja administracyjna - data wygaśnięcia prawa ochronnego na znak towarowy. Glosa do uchwały NSA z dnia 23 kwietnia 2008 r., II GPS 1/08, „Orzecznictwo Sądów Polskich” 2009, nr 1. Stefańska E. (w:) Manowska M. (red.), Kodeks postępowania cywilnego. Komentarz, t. 1, wyd. 3, Warszawa 2015.

69 Z treści opinii Rady Legislacyjnej z 31 maja 2019 roku wynika, że projekt ustawy wymaga daleko idącej korekty, która powinna objąć również usunięcie przepisów, które z uwagi na ich liczne wadliwości systemowe, merytoryczne i techniczno-legislacyjne nie powinny znaleźć się w jego ostatecznej wersji i w przyszłej ustawie - Opinia z 31 maja 2019 r. o projekcie ustawy o zmianie ustawy - Kodeks postępowania cywilnego oraz niektórych innych ustaw, RL-033-21/19. 
Sztobryn K., (Nie tylko) krytyczne spojrzenie na nowe przepisy ustawy prawo własności przemysłowej dotyczące sprzeciwu wobec zgłoszenia znaku towarowego, „Przegląd Prawa Handlowego" 2016, nr 8.

Trzebiatowski M., Zawieszenie postępowania o naruszenie prawa własności przemysłowej ze względu na postępowanie o jego unieważnienie (na tle orzecznictwa), „Przegląd Sądowy” 2015, nr 7-8.

Vall M. du, Prawo patentowe, Warszawa 2008.

Wyroki

Wyrok Sądu Najwyższego z dnia 19 września 1986 r., IV PR 286/86, Lex nr 470982.

Wyrok Sądu Najwyższego z dnia 5 grudnia 1995 r., III CRN 50/95, Lex nr 24941.

Wyrok Sądu Najwyższego z dnia 4 grudnia 1998 r., I PKN 486/98, Lex nr 38787.

Wyrok Sądu Najwyższego z dnia 10 lipca 2002 r., II CKN 826/00, Lex nr 146172.

Wyrok Sądu Najwyższego z dnia 17 czerwca 2004 r., V CK 280/04, Lex nr 137679.

Wyrok Sądu Najwyższego z dnia 24 lutego 2006 r., II CSK 141/05, Lex nr 201027.

Wyrok Sądu Najwyższego z dnia 27 kwietnia 2006 r., I CSK 22/06, Lex nr 490438.

Wyrok Sądu Apelacyjnego w Warszawie z dnia 25 stycznia 2007 r., I ACa 819/06, Lex nr 516527.

Wyrok Sądu Najwyższego z dnia 14 stycznia 2009 r, IV CSK 358/08, Lex nr 603181.

Wyrok Sądu Najwyższego z dnia 30 września 2010 r., I CSK 680/09, Lex nr 622200.

Wyrok Sądu Najwyższego z dnia 15 listopada 2012 r., V CSK 525/11, Lex nr 1276234.

Wyrok Sądu Najwyższego z dnia 16 listopada 2012 r., III CSK 42/12, Lex nr 1293774.

Wyrok Sądu Najwyższego z dnia 18 lutego 2016 r., II CSK 282/15, Lex nr 1991181.

Wyrok Sądu Najwyższego z dnia 2 marca 2017 r., V CZ 15/17, Lex nr 2278332.

Wyrok Sądu Najwyższego z dnia 27 lipca 2018 r., V CSK 384/17, LEX nr 2525421.

Wyrok TSEU z dnia 19 października 2017 r., C-425/16, Lex nr 2376845 .

\section{Uchwaty}

Uchwała Sądu Najwyższego z dnia 29 czerwca 1995 r., II PZP 2/95, Lex nr 23538

Uchwała Naczelnego Sądu Administracyjnego z dnia 23 kwietnia 2008 r., II GPS 1/08, Lex nr 368907.

Uchwała Sądu Najwyższego z dnia 23 lipca 2008 r., III CZP 52/08, Lex nr 408406.

Uchwała Sądu Najwyższego z dnia 11 grudnia 2013 r., III CZP 78/13, LEX nr 1506348.

\section{Postanowienia}

Postanowienie Sądu Najwyższego z dnia 6 listopada 1953 r., I C 1449/53, Lex nr 1633565.

Postanowienie Sądu Najwyższego z dnia 9 lipca 1962 r., I C 82/62, Lex nr 1633518.

Postanowienie Sądu Najwyższego z dnia 14 września 1967 r., I PZ 52/67, Lex nr 6211.

Postanowienie Sądu Najwyższego z dnia 14 października 1980 r., IV PZ 62/80, Lex nr 1671958.

Postanowienie Sąd Najwyższy z dnia 23 sierpnia 1990 r., I CZ 106/90, Lex nr 3664.

Postanowienie Sądu Najwyższego z dnia 30 września 1994 r., III CZP 109/94, Lex nr 4115.

Postanowienie Sądu Najwyższego z dnia 25 lutego 2009 r., II CSK 501/08, Lex nr 528129.

Postanowienie Sądu Najwyższego z dnia 2 marca 2017 r. V CZ 15/17, Lex nr 2278332.

Postanowienie Sądu Apelacyjnego we Wrocławiu z dnia 16 kwietnia 2012 r., I ACz 654/12, Lex nr 1164098.

Inne

Rządowy projekt ustawy o zmianie ustawy - Kodeks postępowania cywilnego oraz niektórych innych ustaw, druk nr 3137 z dnia 8 stycznia 2019 roku.

Rządowy projekt zmiany kodeksu postępowania cywilnego i niektórych innych ustaw z dnia 21 marca 2019 (UD 497).

Dz.U., nr 201, poz. 1615.

Rozporządzenie Rady (WE) nr 6/2002 z dnia 12 grudnia 2001 r. w sprawie wzorów wspólnotowych (Dz.Urz. UE L 2002, nr 3, s. 1).

Rozporządzenia Parlamentu Europejskiego i Rady (UE) 2017/1001 z dnia 14 czerwca 2017 r. w sprawie znaku towarowego Unii Europejskiej (Dz.U. UE L z dnia 16 czerwca 2017 r.).

Projekt Rady Ministrów zmiany kodeksu postępowania cywilnego i niektórych innych ustaw z dnia 21 marca 2019 r. (UD 497). 